\title{
Development of a Quantitative Real-Time Polymerase Chain Reaction (RT- PCR) Assay for Plant Species
}

\section{Kayla Curtis and Heather Miller Coyle*}

Forensic Science Department, Henry C. Lee College of Criminal Justice \& Forensic Sciences, University of New Haven, USA

${ }^{\star}$ Corresponding author: Heather Miller Coyle, Forensic Science Department, Henry C. Lee College of Criminal Justice \& Forensic Science, University of New Haven, USA , Tel. 203-479-4595; E-mail: Hcoyle@newhaven.edu Received Date: January 29, 2014, Accepted Date: February 29, 2014, Published Date: March 27, 2014

Citation: Heather Miller Coyle (2014) Development of a Quantitative Real-Time Polymerase Chain Reaction (RT-PCR) Assay for Plant Species J Forensic Res Crime Stud 1: 1-5

\begin{abstract}
In order to facilitate optimal plant DNA quantitation and identification, an assay has been developed that uses generic plant PCR primers that amplify a region in the chloroplast genome of plant samples. The assay uses the SYBR green detection dye to detect the PCR product with a universal PCR primer set to the large subunit of ribulose bisphosphate carboxylase, $r b c L$, but can be used with any of the universal barcode primers for land plants ( $r b c L$, matK, $\operatorname{trnH}$, psbA). Standard dilutions of control wheat DNA of varying concentrations were tested to create a standard curve. Several plant DNA extractions of different species of unknown concentrations were also tested and the concentrations were quantified from the standard curve. This paper discusses the experimental procedures used to develop and optimize a real-time PCR assay for plants in order to detect plant species that is modeled after the human DNA detection system called Quantifiler for forensic applications. In principle, this can be used to quantitate DNA from any chloroplast containing plant species that is present as trace material at a crime scene, grass stains, or for food and drug analysis.
\end{abstract}

Keywords: RT-PCR Assay; Plant Species; rbcL, DNA Quantitation, Cannabis

\section{Introduction}

Identifying plant material solely based on morphological features can be challenging, but when these plant materials are dried, ground into small particles, or in mixtures, as one might find in spices, teas, or other food products, the challenge of identifying the plant substance becomes even more difficult [1-3]. Even though there is a significant amount of scientific literature on identifying plant species based on their morphological characteristics, it is a time consuming process and mistakes can easily be made if the specimen is fragmented, pulverized or has significant shared morphology between species. If the plant substance is dried or ground up, identifying the plant based on morphology can be impossible making it necessary to develop a DNA method to identify plant materials.

Quantitative real-time polymerase chain reaction (qRT-PCR) provides a way to detect and quantify a species based on a specific region and sequence of DNA [4]. Detection of the RT-PCR product requires the use of a fluorescent dye; a common choice being SYBR Green I. SYBR Green I dye binds to double stranded DNA, emitting fluorescence upon binding. The amount of fluorescence is directly proportional to the quantity of the PCR product [5]. There are real-time PCR assays for all sorts of biological specimens, [6] and the method is widely used and accepted in the scientific and legal community, but a standardized assay for the universal detection of plant materials has not been conveniently available in forensic science laboratory procedures until now. This report describes the experimental procedures used to develop and refine the parameters of a RT-PCR assay for universal identification of plants by chloroplast DNA to achieve optimal detection and quantitation.

\section{Materials and Methods}

\section{Reagents and kits}

A QIAgen Quality QuantiFast ${ }^{\circ} \mathrm{SYBR}^{\circ}$ Green PCR kit (QIAGen; Venlo, Netherlands) was used to detect the PCR product. The components of the kit were stored at $-20^{\circ} \mathrm{C}$ until they were needed and then stored at $2-8^{\circ} \mathrm{C}$ while in use.

\section{Preparation of Standards}

A series of dilutions, from the genomic wheat DNA (stock concentration, $530 \mathrm{ng} / \mu \mathrm{L}$ ), (BioChain; Newark, CA) were made to final concentrations of $5.30 \mathrm{ng} / \mu \mathrm{L}, 0.53 \mathrm{ng} /$

(C)2013 The Authors. Published by the JScholar under the terms of the Creative Commons Attribution License http://creativecommons.org/licenses/by/3.0/, which permits unrestricted use, provided the original author and source are credited. 
$\mu \mathrm{L}, 0.053 \mathrm{ng} / \mu \mathrm{L}, 0.0053 \mathrm{ng} / \mu \mathrm{L}$, and $0.00053 \mathrm{ng} / \mu \mathrm{L}$ (set1). With these concentrations, amplification product at $5.30 \mathrm{ng} /$ $\mu \mathrm{L}$ and $0.53 \mathrm{ng} / \mu \mathrm{L}$ concentrations were observed but not at lower concentrations so additional sets of DNA dilutions were designed and tested for optimal amplification across the range of standards to include 5 sets of dilutions. Computer modeling in Microsoft Excel was used to optimize a standard curve that would have an $\mathrm{R}^{2}$ value of 0.96 and no outlier data points. With the information from the computer modeling a final set of dilutions was used as standards to create a standard curve. This set included standards with concentrations of $13.25 \mathrm{ng} / \mu \mathrm{L}, 5.30 \mathrm{ng} / \mu \mathrm{L}, 2.65 \mathrm{ng} / \mu \mathrm{L}$, and $1.99 \mathrm{ng} / \mu \mathrm{L}$.

\section{Plant DNA Samples}

A marijuana DNA sample was used as a positive control (MJ10) and had been previously extracted and DNA sequenced for quality control and confirmation of species. The sequence matched to Cannabis sativa strain Purple Kush (gb/ AGQN01001883.1) in the GenBank database. Two other sequence verified marijuana DNA samples were also used (MJ3 and MJ4) as unknowns to test the assay. These marijuana DNA samples were stored at $-25{ }^{\circ} \mathrm{C}$ until they were needed and then stored at $2-8{ }^{\circ} \mathrm{C}$ while they were being used in the assay. The marijuana samples were generously collected by law enforcement agencies and arranged for testing through a collaborative agreement with Tommy LaNier, Director of the National Marijuana Initiative, San Diego, CA.

Four other different plant DNA samples were used to test the assay to see if the samples would be amplified and if from the standard curve they could be estimated for DNA concentration. The first was a DNA sample, extracted in June 2010, from the leaf of a Beech tree; the second and third samples were two different DNA extractions, extracted in 2007, from two plants with a genus classification of Sutera, from a previous civil patent case. The fourth sample was a DNA sample from $H$. vulgare also known as barley. The source for most samples was from previous research studies from Dr. Heather Miller Coyle; University of New Haven, West Haven, CT).

\section{RT-PCR Primers}

Three different primer sets were used during this study, two $r b c L$ primer sets and a $\operatorname{rnH}$ primer set as a core barcode for land plants. The first two primer sets used were designated rbcL1f-rbcLWr and trnH-psbATr. Both of these PCR primer sets were supplied by Neil Schultes; (The Connecticut Agricultural Experiment Station; Hamden, CT). The third primer set was a custom primer pair designated rbcLZ1-rbcL895R, also a generic primer that amplifies a region in the chloroplast genome (Life Technologies; Grand Island, NY). These three primer sets were suspended in sterile water and stored at -25 ${ }^{\circ} \mathrm{C}$ until they were needed and stored at $2-8{ }^{\circ} \mathrm{C}$ while in use.

\section{PCR Conditions}

The optimal PCR cocktail used $12.5 \mu \mathrm{L}$ of SYBR Green dye mix, $1 \mu \mathrm{L}$ of each primer in the $r b c L Z 1 / r b c L 895 \mathrm{R}$ primer set, $1.5 \mu \mathrm{L}$ of sterile DNase/RNase free water, and $9 \mu \mathrm{L}$ of the sample. The Applied Biosystem 7500 Real-Time PCR System parameters for this procedure were the following: five minutes at $95 \mu \mathrm{C}$ followed by 35 cycles of three stage PCR: $94 \mu \mathrm{C}$ for one minute, $55{ }^{\circ} \mathrm{C}$ for one minute and then $72{ }^{\circ} \mathrm{C}$ for one minute. When analyzing the amplification plot, analysis was set to manual and the threshold was set at 0.060 for all trials.

\section{Results}

After trying several sets of dilutions to serve as standards in order to generate a good standard curve that met our preset quality criteria, the fifth set of standard dilutions generated the best standard curve, which was then used to quantify the concentrations of unknown samples tested along with the standards. This set of four standards had concentrations of $13.25 \mathrm{ng} / \mu \mathrm{L}, 5.30 \mathrm{ng} / \mu \mathrm{L}, 2.65 \mathrm{ng} / \mu \mathrm{L}$, and 1.99 $\mathrm{ng} / \mu \mathrm{L}$, all of which were made from the standard genomic wheat DNA of known quantity. On average, for PCR tests in plants, 1 to $10 \mathrm{ng}$ of DNA is required which simply reinforces we have the correct range for our choice of standards.

Throughout the trials of this research the best results were obtained with the PCR conditions specified above. The Applied Biosystem 7500 system software suggested that when using the SYBR green dye that a dissociation stage should be added but optimal results were achieved without one, so a dissociation stage is not needed. When analyzing the amplification plot once the PCR reaction was finished, manual analysis of the amplification plot was used and the threshold was set at 0.060 before the amplification plot was analyzed.

All three primer sets worked in this assay to yield a PCR product. The positive controls in each of the trials always amplified above the detection threshold regardless of what primer set was used, it was the standards that didn't always amplify, not because the primers didn't work but because the concentrations of the standards were too low to begin with. This was corrected by adjusting the range of concentrations the set of standards included. If the primers did not work, then there would not have been any amplification even in the positive controls, which there was. The third set of $r b c L$ primers, $r b c L Z 1$ $r b c L 895 R$, was the primer set used in the three replicate trials where the best results were achieved and would seem to be the best choice of primers for this assay, but all have the potential to perform well in this assay. Each of the three PCR primer sets commonly known as the core barcode for land plants bind to the chloroplast region in the plant genome. Since all plants have chloroplasts then any of these three primers would be suitable for this assay and could be substituted in individually to the PCR cocktail for detection of plant DNA $[7,8]$.

With these conditions and set of standards we performed three replicate trials with the same protocol to make sure that the results were not only reproducible but the three trials could be compared to one another to see which trial gave the best results (Table 1). The goal in developing this assay was to model it after the human Quantifiler kit, where the standard curves would have a slope of -3.5 to -3.8 and have optimal $R^{2}$ values in the range of 0.9-1.0 as acceptable criteria for our assay[9].

The first replicate produced a standard curve that had a slope of -5.21 , had an $\mathrm{R}^{2}$ value of 0.96 and quantified the positive control; sample MJ10, to have a concentration of $2.91 \mathrm{ng} / \mu \mathrm{L}$. In the amplification plot of the first replicate each 
of the standards crossed in sequential order, the standards with the higher concentrations crossing before the standards with the lower concentrations, which was as expected. the three trials. This can be attributed to the fact that in each of the three trials the slope and $\mathrm{R}^{2}$ values varied for each of the standard curves, the $\mathrm{R}^{2}$ determines how well the trend line

\begin{tabular}{|c|c|c|c|c|c|c|c|c|}
\hline \multicolumn{3}{|c|}{ Replicate 1} & \multicolumn{3}{|c|}{ Replicate 2} & \multicolumn{3}{|c|}{ Replicate 3} \\
\hline & Ct & Qty & & $\mathrm{Ct}$ & Qty & & $\mathrm{Ct}$ & Qty \\
\hline Standard 1 & 22.81 & $13.25 \mathrm{ng} / \mu \mathrm{L}$ & Standard 1 & 22.48 & $13.25 \mathrm{ng} / \mu \mathrm{L}$ & Standard 1 & 21.94 & $13.25 \mathrm{ng} / \mu \mathrm{L}$ \\
\hline Standard 2 & 25.18 & $5.3 \mathrm{ng} / \mu \mathrm{L}$ & Standard 2 & 23.23 & $5.3 \mathrm{ng} / \mu \mathrm{L}$ & Standard 2 & 23.63 & $5.3 \mathrm{ng} / \mu \mathrm{L}$ \\
\hline Standard 3 & 26.01 & $2.65 \mathrm{ng} / \mu \mathrm{L}$ & Standard 3 & 25.09 & $2.65 \mathrm{ng} / \mu \mathrm{L}$ & Standard 3 & 25.05 & $2.65 \mathrm{ng} / \mu \mathrm{L}$ \\
\hline Standard 4 & 27.47 & $1.99 \mathrm{ng} / \mu \mathrm{L}$ & Standard 4 & 25.72 & $1.99 \mathrm{ng} / \mu \mathrm{L}$ & Standard 4 & 24.79 & $1.99 \mathrm{ng} / \mu \mathrm{L}$ \\
\hline $\begin{array}{l}\text { Positive } \\
\text { control }\end{array}$ & 26.3 & $2.91 \mathrm{ng} / \mu \mathrm{L}$ & $\begin{array}{l}\text { Positive } \\
\text { control }\end{array}$ & 25.72 & $1.77 \mathrm{ng} / \mu \mathrm{L}$ & $\begin{array}{l}\text { Positive } \\
\text { control }\end{array}$ & 25.99 & $1.19 \mathrm{ng} / \mu \mathrm{L}$ \\
\hline \multicolumn{3}{|c|}{ Standard Curve: } & \multicolumn{3}{|c|}{ Standard Curve: } & \multicolumn{3}{|c|}{ Standard Curve: } \\
\hline Slope: & & -5.21 & Slope: & & -4.03 & Slope: & & -3.77 \\
\hline $\mathrm{R}^{2}:$ & & 0.96 & $\mathrm{R}^{2}:$ & & 0.935 & $\mathrm{R}^{2}:$ & & 0.95 \\
\hline
\end{tabular}

Table 1: Results for three replicate RT-PCR assays using the $r b c L$ PCR primers for detection. Ct values represent the PCR cycle number at which the sample crossed the analytical threshold of the amplification plot and Qty values represent the concentrations of the samples. Replicate 3 meets the quality control criteria for the assay.

Since the positive control crossed at a cycle number between the third and fourth standard, it would be expected that the concentration of the positive control would be between the concentration of the third standard, $2.65 \mathrm{ng} / \mu \mathrm{L}$, and the fourth standard $1.99 \mathrm{ng} / \mu \mathrm{L}$, however from the standard curve the positive control was quantified at a concentration slightly higher than the third standard. This shows us that the accuracy would be improved with the addition of one or more standards at the lowest end of the standard curve which is where the positive control value consistently quantifies. The addition of other standards on the lower end of the scale would allow for a best fit line to be plotted between all the standards of known concentration with greater accuracy, however, the 1ng concentration is also near the limit of detection for this assay. This replicate failed our quality control criteria for slope value.

The second replicate produced a standard curve with a slope of -4.03, had an $\mathrm{R}^{2}$ value of 0.94 , and quantified the positive control to have a concentration of $1.77 \mathrm{ng} / \mu \mathrm{L}$. This replicate failed the quality control criteria for slope as well and was rejected for use. The likely largest source of error in any PCR assay is pipetting error and this was the best explanation for the slope issue with the standard curves in replicates 1 and 2 .

The third and final replicate generated a standard curve that had a slope of -3.77 , an $\mathrm{R}^{2}$ value of 0.95 , and quantified the positive control at a concentration of $1.19 \mathrm{ng} / \mu \mathrm{L}$. The positive control crossed the threshold of the amplification plot after all of the standards, and would be expected to have a concentration lower than all of the standards and performed as expected. Replicate 3 was consistent with acceptance criteria, and represents the best estimate for the MJ10 positive control Cannabis sample.

Each of the positive controls in the three replicate trials amplified and passed over the threshold at about the same time, however the calculated concentrations varied in each of fits the set of data points and if the trend line does not always fit perfectly, it will skew the calculated results and causes the quantified concentrations to vary slightly. The slope value however was most critical in determining best fit to the human real-time PCR assay system used in forensic DNA analysis. This illustrates the importance of using both of the quality control criteria in accepting the standard curve; this is similar to that criteria used for human DNA quantitation methods.

Results were obtained with the six other plant samples that were used as unknowns to test the assay. The sample from the leaves of the beech tree, the barley DNA sample, and both Cannabis samples were all amplified above the analysis threshold and able to be quantified. A representative RT-PCR plot and standard curve is shown in figure 1 . The quantity for the two Cannabis samples is shown in Table 2. The two Sutera plant samples did amplify by RT-PCR but could not be analyzed as they did not meet the analysis threshold. They were very old liquid DNA extracts, six to seven years old, and were likely severely degraded or too limited in quantity for detection.

\section{Discussion}

The goal of this research was to computer model and develops a real-time PCR assay for land plants using any of three typical core DNA barcode regions as targets. Our results show that this assay is a functional assay for detection of several different plant species, and has the potential to work with multiple plant specific (chloroplast) PCR primers. The advantage to having a simple ubiquitous plant realtime PCR assay is that green powders can be rapidly tested to establish if they contain chloroplast DNA, an indicator of plant substances, or if the powder is of a chemical rather than biological origin. As a second classification step, PCR products from this assay can be cloned and DNA sequenced to confirm the identity of most plant species by matching back to a reference DNA sequence database of known species. 
As a potential public safety and health issue, the identity of green powders or other plant-based products found in the mail, at crime scenes, in clothing stains, or distributed as food, drugs or medicine, and as components of herbal commercial products can be in question.

\section{Acknowledgements}

We are grateful to Dr. Neil Schultes, at The Connecticut Agricultural Experiment Station (CAES) in New Haven, CT for providing the $r b c L 1 F / r b c L W r$ and $\operatorname{trnH} / \mathrm{psbATr}$ primer sets; and to Amanda Dogul for performing DNA sequenc

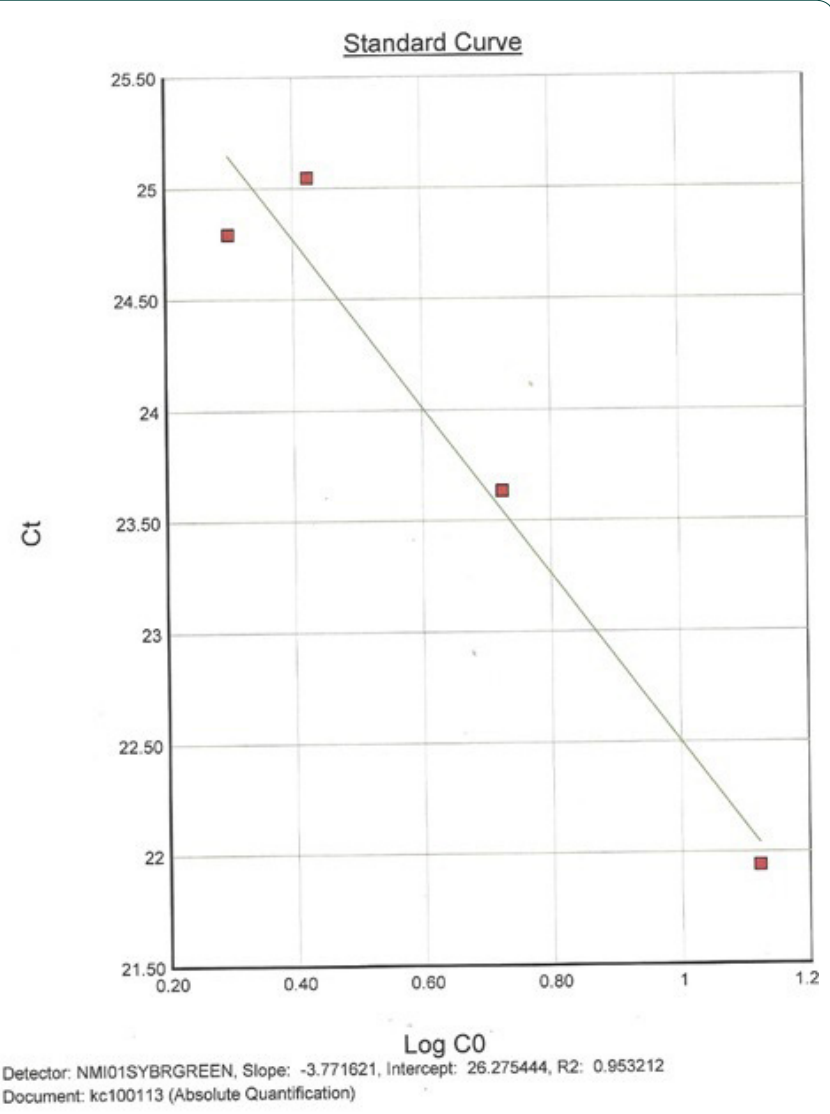
Detector: NM101SYBRGREEN, Slope: -3.771621, Intercept: 26.275444, R2: 0.953212
Document: kc100113 (Absolute Quantification)

Figure 1. A representative RT-PCR assay plot (A) and standard curve (B) for detection of chloroplast DNA.

A. Amplification plot shows PCR product of four wheat DNA samples used to generate the standard curve, one marijuana positive control and two unknown marijuana samples for quantitation. The negative control did not amplify in the plot as expected.
B. Standard Curve [cycle threshold number $(\mathrm{Ct}) \mathrm{x}$ DNA concentration $(\log \mathrm{CO})]$

\begin{tabular}{|l|l|r|r|}
\hline & Sample & \multicolumn{1}{|c|}{ Ct } & \multicolumn{1}{c|}{ Qty } \\
\hline \multirow{2}{*}{ Replicate 3} & MJ3 (marijuana) & 21.5 & $18.43 \mathrm{ng} / \mu \mathrm{L}$ \\
\cline { 2 - 4 } & MJ4 (marijuana) & 25.77 & $1.36 \mathrm{ng} / \mu \mathrm{L}$ \\
\hline & MJ10 (marijuana) & 25.99 & $1.19 \mathrm{ng} / \mu \mathrm{L}$ \\
\hline
\end{tabular}

Table 2: Results of the RT-PCR assay for detection of positive control (MJ10) and evidentiary marijuana samples (MJ3, MJ4). The Ct value represents the cycle number at which the sample crossed the threshold of the amplification plot. The Qty value represents the calculated DNA concentration of each of the samples when plotted against the wheat DNA standard curve.

The ability to quickly assay small quantities of extracted DNA from green powders and establish if they are of plant origin along with the option to sequence the PCR products either directly or indirectly to verify the genus and species for identification is advantageous. Potential applications for this assay include, for example, identification of smuggled powders across United States borders, for poison control for allergic reactions and overdose symptoms, and the enforcement of food and drug safety policies. -ing of positive control marijuana samples in collaboration with CAES. Thank you to Tommy LaNier of the National Marijuana Initiative in San Diego, California for providing the marijuana DNA samples used in this research. Thank you to the Office of National Drug Control Policy, the National Marijuana Initiative and University of New Haven for funding this research. The views expressed in this article are those of the authors and not necessarily the agencies providing funding. 


\section{References}

1) Xiao-Feng Wanga, De-Shuang Huanga, Ji-Xiang Dua, Huan Xua, Laurent Heutte (2008) Classification of Plant Leaf Images with Complicated Background. Appl Math Comput 205: 916-926.

2) Dev G, Asis K (2012) Morphological and Anatomical Circumscription for the Identification of Two Source Plants of Aphrodisiac Medicine - Chlorophytum borivilianum Santapau \& Fernandes and Chlorophytum tubersum. Int J Med Arom Plants 2: 406-410.

3) Stoeckle M (2011) Commercial teas highlight plant DNA barcode identification successes and obstacles. Scientific Reports 1-7.

4) QuantiFast SYBR Green PCR Handbook.
5) Critical Factors for Successful Real Time PCR.

6) Johnson CE, Premasuthan A, Satkoski Trask J, Kanthaswamy S, (2013) Species Identification of Cannabis sativa Using Real-Time Quantitative PCR. J Forensic Sci 486-490.

7) Whitlock B, Hale A, Groff P (2010) Intraspecific Inversions Pose a Challenge for the trnH-psbA Plant DNA Barcode. Plos One 1-7.

8) Chodon Sass, Damon Little P, Dennis Wm Stevenson, Chelsea Specht D (2007) DNA Barcoding in the Cycadales: Testing the Potential of Proposed Barcoding Markers for Species Identification of Cycads. Plos One 1-9.

9) Quantifiler Human DNA Quantification Kit and Quantifiler ${ }^{\circledR}$ Human Male DNA Quantification Kit User Manual.
Submit your manuscript to JScholar journals and benefit from:

- Convenient online submission

ฯ Rigorous peer review

- Immediate publication on acceptance

- Open access: articles freely available online

9 High visibility within the field

- Better discount for your subsequent articles

Submit your manuscript at http://www.jscholaronline.org/submit-manuscript.php 